\title{
半能動制御形防振器で支持された配管の 振動台による地震応答試験*
}

\author{
下田 博 一** 大亦絢一郎** 岡 本 文 明***
}

Shaking Table Tests of a Piping System Supported by a Semiactive Damper

Hirokazu Shimoda, Kenichiro Oнmata and Fumiaki Окамото

The present report is concerned with the results of shaking table tests of L-shaped piping supported by the semiactive damper which the authors have developed for piping systems. The damper is composed of a ball screw, a disk brake and piezoelectric actuators. The brake force is controlled corresponding to seismic responses of the piping or input accelerations. L-shaped piping of length $3 \mathrm{~m} \times 3 \mathrm{~m}$ and outer diameter $60.5 \mathrm{~mm}$ is used as a piping model in shaking table tests. Both ends of the L-shaped piping are rigidly attached to the shaking table through supporting walls. The semiactive damper is attached between the bent section of the piping and the shaking table. Input accelerations used here are EL Centro (1940) NS and Akita (1983) NS normarized to be $2 \mathrm{~m} / \mathrm{s}^{2}$ at the maximum acceleration. The results may be summarized as follows: (1) The deflection of the L-shaped piping can be reduced successfully by the semiactive damper. (2) The semiactive damper has the effect of vibration suppression even by simple control method such as on-off control or proportional control. (3) The results of shaking table tests of the piping agree approximately with the calculated results.

Key words : shaking table test, vibration suppression, seismic response control, earthquakeproof device, semiactive damper, L-shaped piping, piping system, piezoelectric actuator, ball screw

\section{1. は じめに}

一般の配管系に対する耐震用防振器としては, コス 卜面における優位性から油压防振器が広範用に使用さ れている，一方，高温・放射線䨌囲気などにさらされ ることの多い火力・原子力発電所や化学プラント等に おいては, 巨大地震発生時の配管系の安全性, 信頼性 が最重要課題であり, 防振器の耐震性能の向上ととも に，耐環境性能ならびにメンテナンスフリー化に対す る要求が一段と箃しくなっている.メカニカルスナッ バは，耐熱性，保守性に優れた剛支持形の耐震装置で あり, 従来より原子力発電所等において多用されてき たが，構造の簡素化，低価格化を伴ったこれ以上の性 能向上には限界があることから，近年になって，防振 器により積極的に減衰を付与し，配管を柔構造のまま で振動を抑制しょらとする気運が見られる1)。した

\footnotetext{
* 原稿受付 平成 5 年 1 月 21 日

** 正 会 員 明治大学理工学部（川崎市多摩区東三田 1-11)

*** JR 東日本（東京都千代田区丸の内 1-6-5）
}

がって, 高温・放射線䨌囲気中に打ける配管系を対象 とした耐震装置の開発ならびにその性能向上を図るた めには, 今後さらに防振器をアクティブコントロール タイプとし2), 制御技術, アクチュエータ技術, セン シング技術等の積極的な応用が不可欠であり, 精密工 学分野からのアプローチも重要なポイントになろらか と考光る.

本研究の目的は，高温・放射線雾囲気中に扔かれた 配管系を対象とし, 構造が簡単で地震応答抑制効果に 優れた防振器を開発することにある. 現在までのとこ ろ, 振動台を用いた配管用防振器の性能試験は数多く 行われているが，そのほとんどがパッシブタイプの防 振器に関するものである. 本研究では, セミアクティ ブタイプの防振器により支持した配管の地震応答につ いて振動台による検証試験を実施するものであり，こ の点も本研究の特色として挙げられる.

前報 ${ }^{3)}$ では，欧電アクチュエータを用いたディスク ブレーキおよびボールねじから成る半能動制御形防振 器を提案し, この防振器をL 字形配管に取り付けた とさの地震応答についてシミュレーションを行った. 


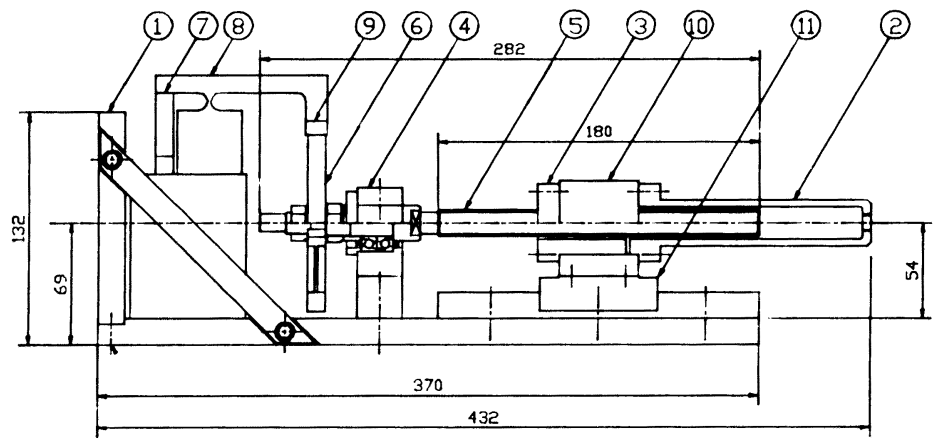

(1) Base, (2) Load column, (3)Ball nut, (4) Ball bearing, (5)Screw shaft, (6)Brake disk, (7)Piezoelectric actuator, (8)Brake lever, (9)Brake shoe, (10Bracket, (11) Linear motion bearing

Fig. 1 Structure of the semiactive damper

本報では, 前報で提案した防振器を試作するととも に, この防振器で支持された $\mathrm{L}$ 字配管を電気油圧式 振動台に取り付け，振動台に地震波を入力したときの 配管の地震応答試験を実施した。 また，前報で述べた シミュレーション結果との比較を行うとともに, 防振 器に対する制御方法を種々に变化させることで, 本防 振器に打ける地震応答抑制効果と制御条件との関係に ついても検討を行ったので，これらの結果について報 告する.

\section{2. 防振器と試験装置の概要}

試作した半能動制御形防振器の構造と主要寸法を図 1 に, また防振器を振動台に取り付けたときの外観を 図 2 に示寸，地震応答試験に際しては, 防振器のべー ス (1) が床 (振動台) に，ロードコラム (2) が配管に取 り付けられる。いま，床と配管の間に相対変位が生じ たとすると，ナット(3)は直線方向に運動し，アン ギュラ玉軸受 (4)で固定されたねじ軸 (5) 拉よび ブレーキディスク (6)が回転運動する.ディス クブレーキは積層型压電素子 (7), ブレーキレ バー (8), ブレーキシュー (9) から構成されてい る. ここで，ナットに働く偏荷重の影響を除去 し，ボールねじを円滑に運動させる目的から， ボールねじのナットはブラケット (10)を介して 直動転がり軸受 (11)により案内されている。そ こで，圧電素子に所定の電圧を印加すれば，ブ レーキシューがブレーキディスクに押し付けら れ, 回転軸系に対し制動トルクを発生させるこ とができる.

振動台に L 字配管を設置し, 配管屈曲部に 防振器を取り付けた状態を図 3 に示す。ただ

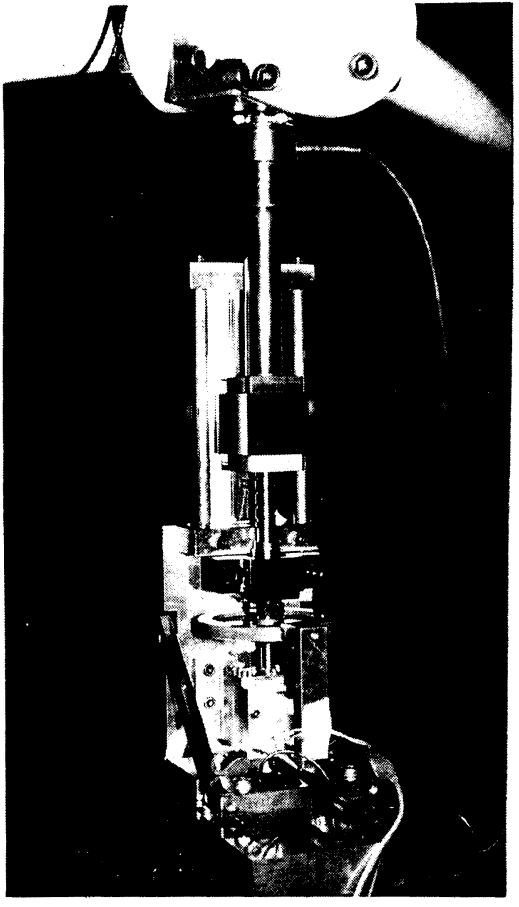

Fig. 2 Appearance of the semiactive damper

し，本研究は壁に設置した L 字配管の水平方向振動 を想定したものであるが，実験装置の構造上の制約か ら，床（振動台）に設置した L字配管を垂直方向に 加振することにした。

L字配管の材質はSTPG 42 で, 一辺の長さが 3 $\mathrm{m}$, 外径は $60.5 \mathrm{~mm}$ である. ただし, 振動台のテー ブル上面の寸法が $1.5 \mathrm{~m} \times 1.5 \mathrm{~m}$ であるため，I形銅

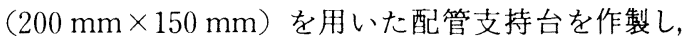
振動台上から水平方向に $1.5 \mathrm{~m}$ だけオーバハングさ せている．ここで，配管支持台の曲げ剛性は配管と比

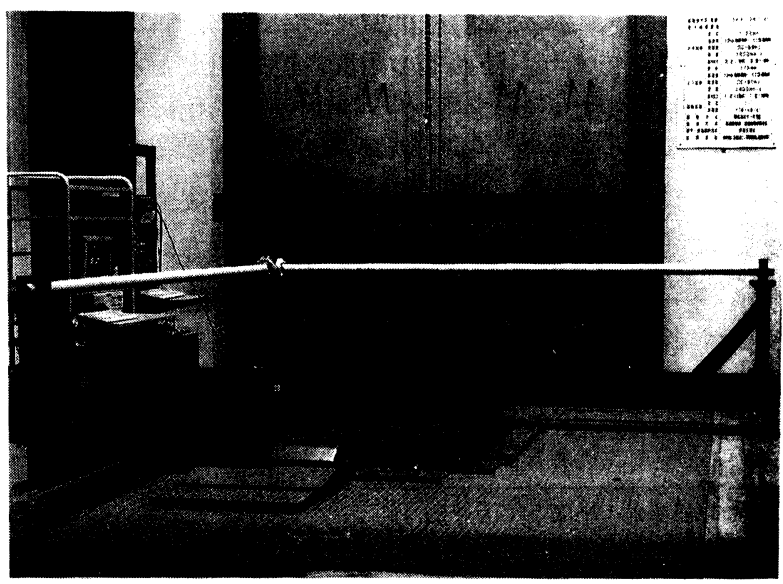

Fig. 3 L-shaped piping on the shaking table 
Table 1 Specifications of the damper and the L-shaped piping

\begin{tabular}{l|l}
\hline \multicolumn{2}{c}{ Damper } \\
\hline Lead of ball screw & $10 \mathrm{~mm}$ \\
Moment of inertia & $548 \mathrm{~kg} \cdot \mathrm{mm}^{2}$ \\
Radius of brake disk & $50 \mathrm{~mm}$ \\
Coefficient of friction & 0.3 \\
\hline
\end{tabular}

\begin{tabular}{l|l}
\hline \multicolumn{2}{c}{ Piezoelectric actuators } \\
\hline Displacement & $30 \mu \mathrm{m} / 100 \mathrm{~V}$ \\
Force & $3430 \mathrm{~N} / 100 \mathrm{~V}$ \\
Dimension & $10 \times 10 \times 36 \mathrm{~mm}$ \\
\hline
\end{tabular}

\begin{tabular}{l|l}
\multicolumn{2}{c}{ L-shaped piping } \\
\hline Material & STPG 42 \\
Young's modulus & 208 GPa \\
Outer diameter & $60.5 \mathrm{~mm}$ \\
Wall thickness & $5.5 \mathrm{~mm}$ \\
Length & $3 \mathrm{~m} \times 3 \mathrm{~m}$ \\
Weight per length & $7.46 \mathrm{~kg} / \mathrm{m}$ \\
\hline
\end{tabular}

較して約 120 倍に設計されている. あらかじめ, 正弦 波および地震波を用いて振動台を垂值方向に加振した 際の配管両端部（配管固定部）の吢答変位を夷測した ところ，両者の差異は $5 \%$ 以下であり，配管支持台が 十分な剛性を有することを確かめた.

振動台は, 垂直・水平同時加拢の叮能な電妏一油压: サーボ方式を採用した 2 次元振動台であるが，本象験 では垂直方向にのみ加振する，振動台の最大載荷重量 は1000 kg，加振周波数範囲は DC〜 $50 \mathrm{~Hz}$ である. また，垂直方向に対してはストローク さ75 mm，最 大速度 $400 \mathrm{~mm} / \mathrm{s}$, 最大加速度 $2 \mathrm{G}$ までのランダム波 出才が可能である. また, 加张機とテーブルの連結部 およびテーブルの運動はすべて静压軸受で案内されて おり，入力波形の再現精度は高い。なお，防振器なら びにL字形配管の諸元は表 1 にまとめて亦す。

\section{3. 防振器の各種性能試験}

地震応答試験に先だち，ブレーキ装置の各種性能な らびに防振器の抵抗力特性について奏験を行った.

本防振器のブレーキ装置に用いた压電アクチュエー タに対しては,ブレーキシューとブレーキディスク間 に存在するブレーキギャップを上[回るだけの発生変位 と, 防振器として有効なブレーキ力を得るための発生: 力が同時に要求される.

まず，ブレーキギャップを $0 \mu \mathrm{m}, 10 \mu \mathrm{m}, 25 \mu \mathrm{m}$ に変化させながら, 压電アクチェェータの印加電玨と ブレーキシュー先端に打ける発生ブレーキ力の関係を 調べた結果を図 4 に示す。配管用防振器に対しては, 平常時に打ける抵抗力の少なさと地震発生時における

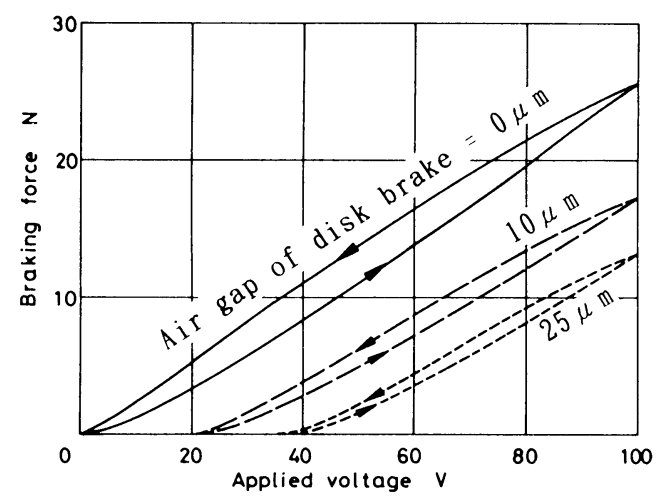

Fig. 4 Braking force of the disk brake

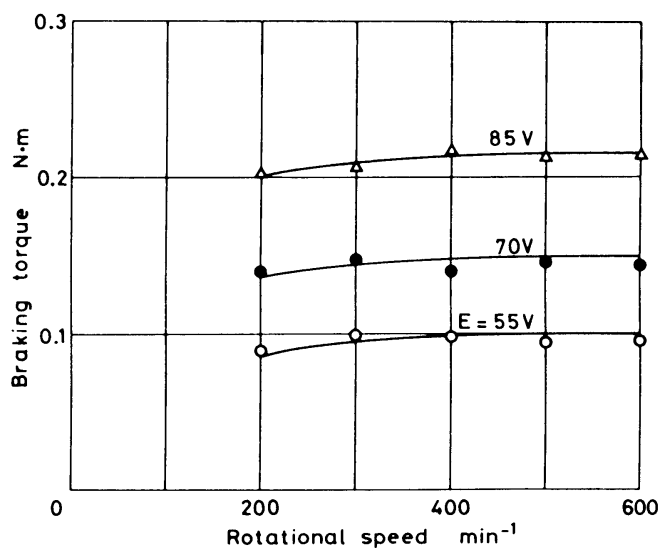

Fig. 5 Braking torque of the disk brake

拘束力の大きさが同時に要求されるので, ブレーキ ギャップは常時維持され，しかもでさるだけ小さい值 が望ましい.したがって, 環境から受ける温度変化や 各部品の組立精度を考慮すれば，設定可能な最小すき まは $10 \mu \mathrm{m}$ 程度と考えられる. 図 4 の測定から, ブ レーキギャップを $10 \mu \mathrm{m}$ に設定した場合，王電アク チュェータの定格電圧 $100 \mathrm{~V}$ に対して $17 \mathrm{~N}$ のブレー キ力の得られることがわかる. そこで, ブレーキ ギャップを $10 \mu \mathrm{m}$ に一定とした状態で, ディスクブ レーキの制動トルクの測定を行ったところ, 図 5 の結 果を得た. この結果に基ついて, ブレーキシューとブ レーキディスク間の摩擦係数を求めると $\mu \fallingdotseq 0.3$ なる 值が得られたので, 以下に述べるシミュレーションで は摩擦係数としてこの值を用いることにした.

次に，ブレーキ装置の応答性を調べるために，王電 アクチュエータに正弦波状の電王を印加してブレーキ シュー先端の応答変位を測定した結果を図 6 に示す. これより，ブレーキの 1 次共振点は $440 \mathrm{~Hz}$ であり， この共振振動数は, ブレーキ装置に用いた変位拡大機 


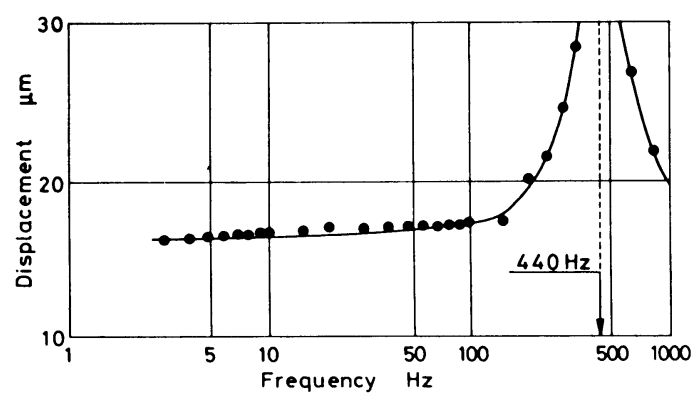

Fig. 6 Resonance curve of the disk brake

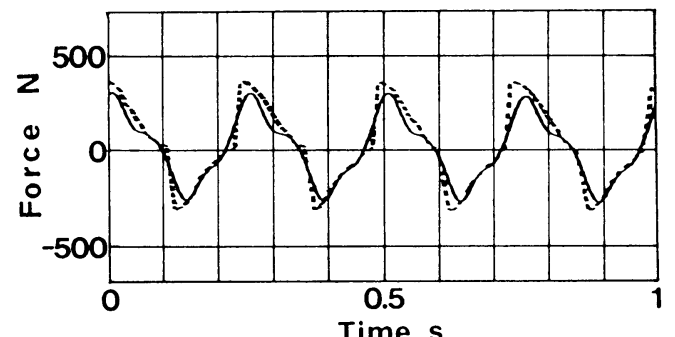

Fig. 7 Time histories of resistance force

構（拡大率：2.5 倍）の 1 次共振点に扣括むね一致し ている. また，一般的に地震波の振動数成分は $20 \mathrm{~Hz}$ 程度までを考えれば十分であることを考慮して，制御 系に打ける A/D，D/A 変換時間を $10 \mathrm{~ms}(100 \mathrm{~Hz})$ に設定することにした.

防振器のベースを振動台に, ロードコラムをロード セルを介して反力壁に固定して，振幅 $1 \mathrm{~mm}$, 振動数 $4 \mathrm{~Hz}$ の正弦波状変位加振を行い, 防振器の抵抗力特 性の測定を行った。図 7 は抵抗力の時刻歴波形を表 し, 図 8 は変位と抵抗力のリサージュ波形を表す。 ま た，図中の実線および破線はそれぞれ実験值およびシ ミュレーション值を表す。これらの結果ならび前報で 述べた地震発生時の防振器に働く抵抗力のシミュレー
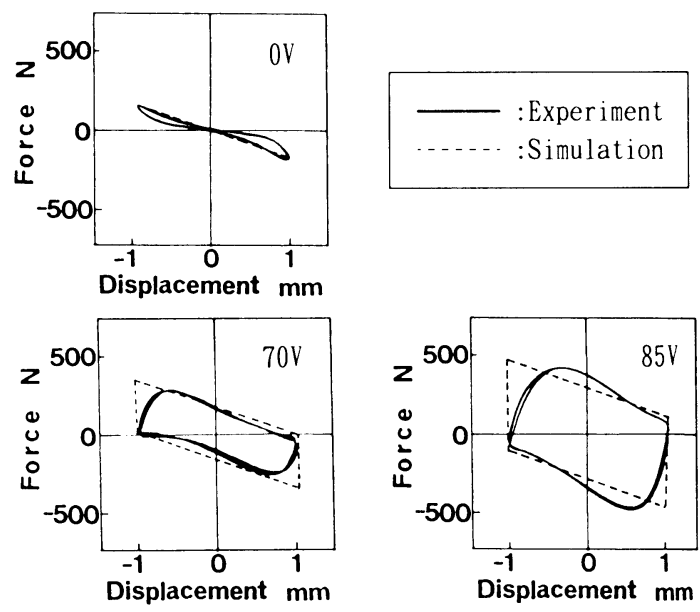

Fig. 8 Lissajous' figure of resistance force/displacement

ション結果から, 試作した防振器が十分な抵抗力を有 することが確かめられた。ただし，リサージュ波形に おける央験值扣よびシミュレーション值間の形状の不 一致, 寸なわちボールねじのナットがその運動方向を 反転する際に生じる波形の丸みは，ボールねじや軸受 部分のがたによる影響が表れているものと思われる.

\section{4. 地震応答試験}

本防振器におけるブレーキ力 $F_{\mathrm{b}}$ の制御条件として は，前報の結果を参考にして以下の 4 通りとした.
(1) $F_{\mathrm{b}}= \begin{cases}10 \mathrm{~N} & \left(\left|\dot{u}_{6}\right| \geqq 0.0005 \mathrm{~m} / \mathrm{s}\right) \\ 0 \mathrm{~N} & \left(\left|\dot{u}_{6}\right|<0.0005 \mathrm{~m} / \mathrm{s}\right)\end{cases}$
(2) $\quad F_{\mathrm{b}}= \begin{cases}10 \mathrm{~N} & \left(\left|\ddot{y}_{\mathrm{H}}\right| \geqq 0.1 \mathrm{~m} / \mathrm{s}^{2}\right) \\ 0 \mathrm{~N} & \left(\left|\ddot{y}_{\mathrm{H}}\right|<0.1 \mathrm{~m} / \mathrm{s}^{2}\right)\end{cases}$
(3) $F_{\mathrm{b}}=4000 \times\left|\dot{u}_{6}\right| \mathrm{N}$
(4) $F_{\mathrm{b}}=0.25 \times\left|\ddot{y}_{\mathrm{H}}\right| \mathrm{N}$

ここで, $\left|\dot{u}_{6}\right|$ 拈よび $\left|\ddot{y}_{\mathrm{H}}\right|$ はそれぞれ L 字形配管の屈

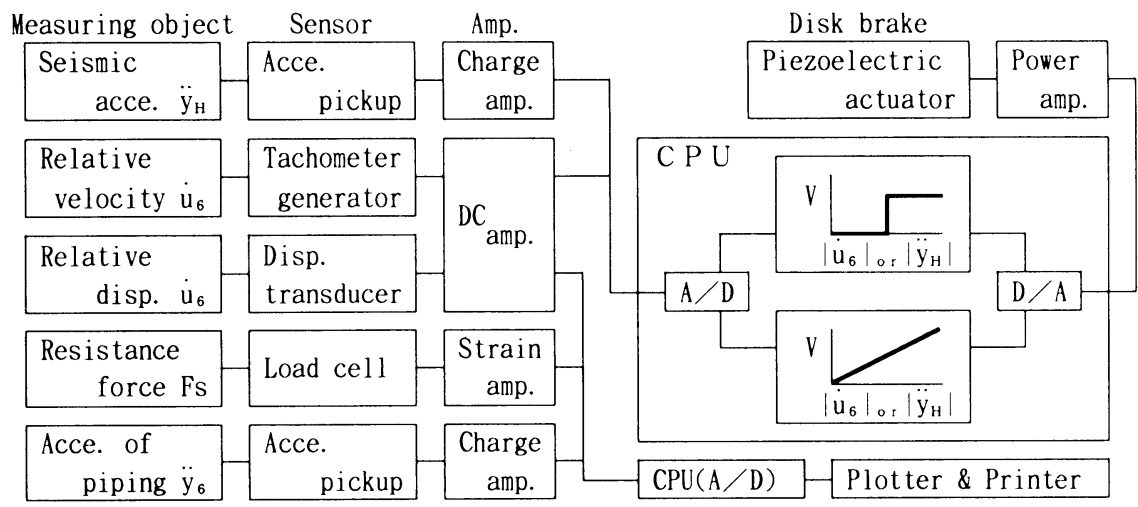

Fig. 9 Measuring and controlling system 
曲部の相対速度および入力地震加速度（振動 台の加振加速度）の絶対值を表し，uの添字 6 はシミュレーションを行う際に, 11 個の質 点系に置き換えた L字配管の屈曲部に拈け る質点番号を表している。なた，上述した制 御条件において，(1)，(2) はオン・オフ制御 に相当し，(3)，(4) は比例制御に相当してい る.

地震応答試験に用いた計測・制御システム は図 9 に示す。制御条件（1），(3) の場合は, ボールねじのねじ軸先端に取り付けたタコ ジェネにより振動台と配管との相対速度が計 測され, 制御条件 (2), (4) の場合は, 振動台 に取り付けた加速度ピックアップにより入力 地震加速度が計測される。これらの計測量 は，パソコンを用いて $\mathrm{A} / \mathrm{D}$ 変換した後, 所 定のしきい値もしくは比例足数を用いて世電 アクチュェータに印加する電比を計算し, さ らに D/A 変換の後, ブレーキ用パワーアン プに入力される。 束た, 防拢器の性能を評価 する目的から，配管屈曲部の相対变位，防拨 器に働く抵抗力扣よび配管痋曲部の加速度も あわせて計測した。

試験結果の…例として, 振動台にImperial Valley 地震 (1940) El centro NS 成分 を最大 $2 \mathrm{~m} / \mathrm{s}^{2}$ に基準化して入おし, 制御条 件（3）执よび（4）を用いたときの，相対変 位, 抵抗力, ブレーキお时時刻歴波形をそれ ぞれ図 10 扣よび図 11 に亦す。ここで, 地震 波はNS 方向成分を用いているが，前述した ように壁に対する水平加振を休（拢動台）に 対する垂直加振に置き換えているので, 地震 波は垂直方向に入力した。 また，ブレーキ力 は压電アクチュェータに印加した電讵に対し て図 4 の結果を適用して求めた值を表す。こ れらの結果から, 配管の必答変位は防振器を 取り付けなかった場合と比較して $1 / 20 〜 1 /$ 30 に低減されており, 配管の曲げ変形の抑 制に対して防振器が有効に動いていることが 確かめられた。 また，今[门]の地震応答試験に より得られた結果と前報で述べたシミュレー ション結果はよく一致して扣り, シミュレー ションの妥当性が検鿉:された.

制御条件を上述した 4 通りに変化し, さらに入力地 震波として日本海中部地震（1983）秋田港 NS 成分を 加えたときの応答変位 $u_{6}$, 加速度 $\ddot{y}_{6}$ 打よび抵抗才
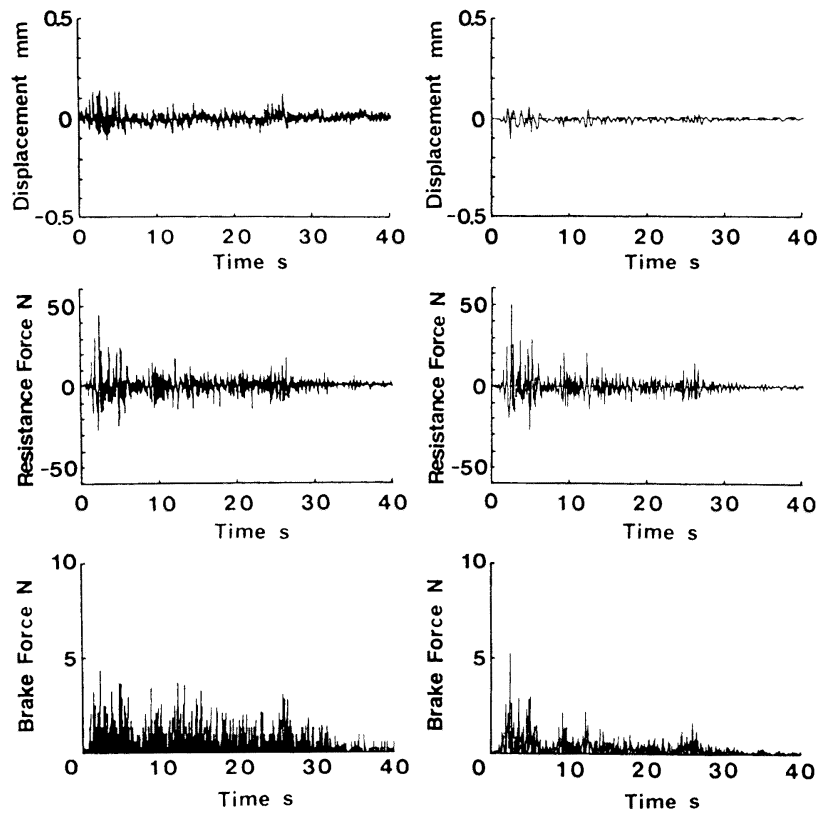

(Experiment)

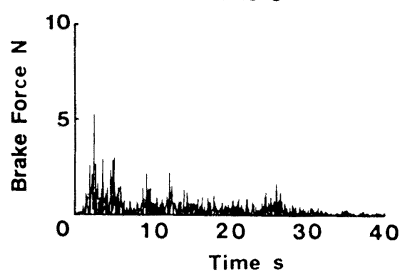

(Simulation)

Fig. 10 Time histories of $u_{6}, F_{\mathrm{s}}$ and $F_{\mathrm{b}}$ (Control condition (3))
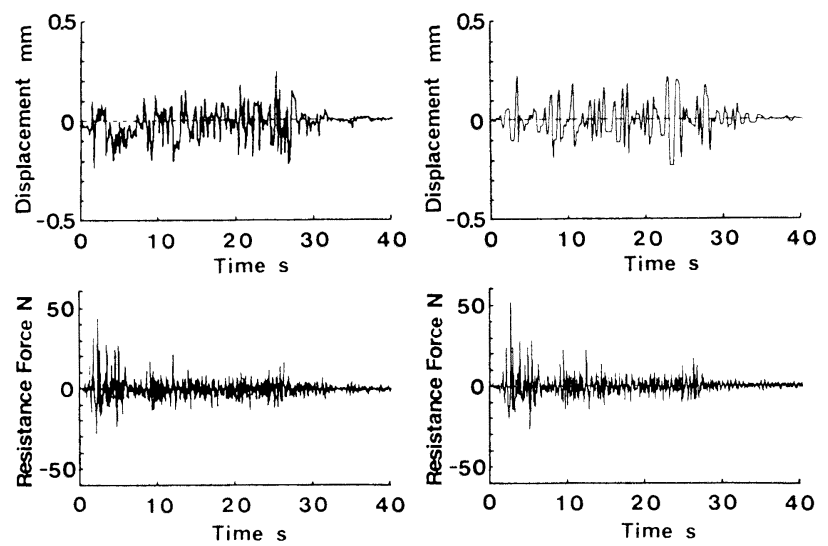

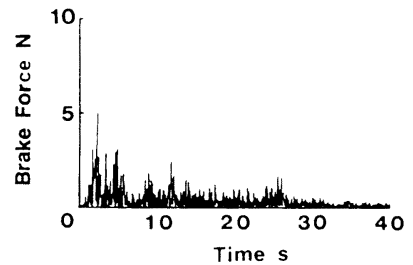

(Experiment)

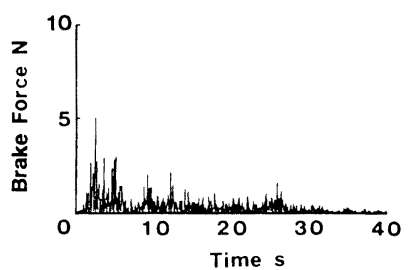

(Simulation)
Fig. 11 Time histories of $u_{6}, F_{\mathrm{s}}$ and $F_{\mathrm{b}}$ (Control condition (4))

$F_{\mathrm{s}}$ の最大值を表 2 によめて示す。ここでは, 試験 条件による防振器の制振性能を比較する目的から, ブ レーキ力八の大きさは, 防振器に働く最大抵抗力がほぼ 同じになるよら設定されている.これらの結果から， 
Table 2 Maxima of relative displacement, acceleration and resistance force

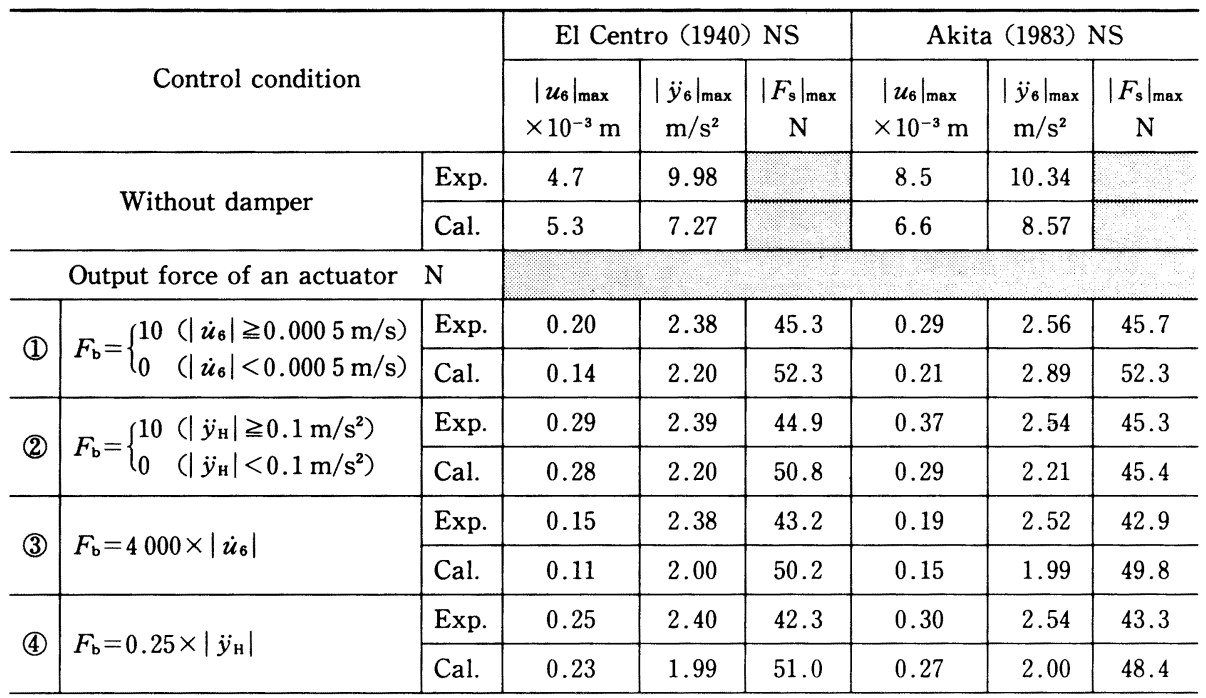

いずれの制御条件を用いた場合でも，またいずれの地 震波を入力した場合でも，配管の応答変位は十分に抑 制されており，本報のよらにオン・オフ制御や比例制 御のような簡単な制御方法を採用した場合であって も，制振効果の大きいことが確かめられた。 また，制 御条件による制振効果の違いを比較した場合，制御条 件 (1)，(3) の方が制御条件 (2)，(4) 上り優れて打り, また，比例制御の方がオン・オフ制御より優れている のがわかる. したがって, 本防振器に执いては, 配管 の相対応答速度による比例制御が最も適していること が明らかとなった。

\section{5. むす び}

圧電アクチュエータを用いた半能動制御形防振器を 試作し，これを L字形配管に取り付けたときの地震 応答について振動台による検証試験を実施するととも に, 前報で述べたシミュレーション結果との比較を 行った.

得られた結果ををとめると以下の通りである.

（1）半能動制御形防振器を試作するとともに, そ の特性を調べたところ，わずかなブレーキ力で あっても配管用防振器として十分な抵抗力が得ら
れた.

（2）振動台による地震応答試験を実施した結果, 本防振器の有効性ならびに前報で述べたシミュ レーションの妥当性が検証された。

（3）本防振器を用いて配管の応答変位を抑制する 際，制御条件としては，配管の相対応答速度によ る比例制御が適している.

終わりに，防振器の製作に際してご協力いただいた 黒田精工(株)に感謝の意を表するとともに，本研究の 地震応答試験が明治大学理工学部振動実験解析棟にお。 いて実施されたことを付記する.

\section{参 考 文 献}

1）浪田芳郎, 重田政之, 好永俊昭, 後藤伸穂, 川畑淳一： 弹塑性形配管支持装置の配管系への適用に関する研究 （第 2 報，支持配管系振動特珄試験のシミュレーション解 析）, 日本機械学会論文集，C編，55，514（1989）1341.

2）小島宏行, 長屋幸助, 新山文彦, 永井克已：速度フィー ドバック形電磁ダンパによるはり状構造物の振動制御, 日本機械学会論文集, C 編, 51，472（1985） 3235.

3）下田博一，岡本文明，大亦維一郎：环電アクチュエータ を用いた半能動制御形防振器による配管の地震応答抑制, 精密工学会誌，58，12（1992）2111. 